\title{
THE DIMENSIONING OF NURSING STAFF ACCORDING TO NURSING COORDINATORS: CONCEPT, AIM AND USE ${ }^{1}$
}

Luciana de Freitas Campos ${ }^{2}$

Marcia Regina Antonietto da Costa Melo

Campos LF, Melo MRAC. The dimensioning of nursing staff according to nursing coordinators: concept, aim and use. Rev Latino-am Enfermagem 2007 novembro-dezembro; 15(6):1099-104.

This study aimed to conceptualize the dimensioning of nursing staff, as it is understood by professionals who realize this task, and also to reveal their aim and use of estimation of nursing human resources. It is a descriptive and exploratory study with a qualitative approach analyzed through Content analysis. The definition obtained corresponds to those found in literature and, as to its aim, it serves to preview the number of professionals; to guarantee the operation of the nursing work; to attend clients' expectations regarding their needs; to provide personnel and to guarantee their allocation in the work scale. As to the use of this definition in personnel management, it provides a justification to increase staff through new contracts.

DESCRIPTORS: personnel downsizing; nursing; organization and administration

\section{VISIÓN DE COORDINADORES DE ENFERMERÍA SOBRE EL CÁLCULO DEL PERSONAL DE ENFERMERÍA: CONCEPTO, FINALIDAD Y UTILIZACIÓN}

La finalidad de este estudio fue la de conceptualizar el cálculo de personal de enfermería de acuerdo con la comprensión de los profesionales que lo hacen y mostrar la finalidad y utilización de la estimación de recursos humanos en enfermería según ellos. Esto es un estudio exploratorio descriptivo del tipo cualitativo. Fue realizado el análisis de contenido. La definición descubierta corresponde a aquellas encontradas en la literatura y, con respecto a la finalidad, sirve para prever el número de profesionales; garante la operacionalización del trabajo de enfermería; cumple la expectativa del cliente con respecto a sus necesidades; provee los sectores de personal y garantir la distribución de los profesionales en la escala. En cuanto a la utilización de la definición en la gestión del personal, sirve como justificación para aumentar el cuadro mediante contractación.

DESCRIPTORES: reducción de personal; enfermería; organización y administración.

\section{VISÃO DE COORDENADORES DE ENFERMAGEM SOBRE DIMENSIONAMENTO DE PESSOAL DE ENFERMAGEM: CONCEITO, FINALIDADE E UTILIZAÇÃO}

Este estudo teve como objetivo conceituar dimensionamento de pessoal de enfermagem, segundo o entendimento dos profissionais que o realizam e desvelar, segundo eles, qual a finalidade e utilização da estimativa de recursos humanos em enfermagem. Trata-se de estudo exploratório-descritivo de natureza qualitativa. Procedeu-se à análise do conteúdo. A definição apreendida vem ao encontro daquelas encontradas na literatura e, quanto à finalidade, serve à previsão dos profissionais, garante a operacionalização do trabalho de enfermagem, atende à expectativa do cliente com relação às suas necessidades, provê os setores de pessoal e garante a distribuição desses, na escala. Quanto à utilização no gerenciamento do pessoal, ocorre como justificativa para aumentar o quadro por meio de contratação.

DESCRITORES: downsizing organizacional; enfermagem; organização e administração

${ }^{1}$ Article extracted from Master Dissertation: ${ }^{2}$ MS in Nursing, Professor Vales do Jequitinhonha e Mucuri Federal University, UFVJM, Brazil, e-mail: lucaenf@ufvjm.edu.br; ${ }^{3}$ PhD Professor, University of São Paulo at Ribeirão Preto, College of Nursing, WHO Collaborating Center for Nursing Research Development, Brazil, e-mail: mracmelo@eerp.usp.br 


\section{INTRODUCTION}

Nursing work is complex and dynamic. It is inserted in the context of public or private health institutions, where it is developed and adjusted to the organizational policy.

Human resources, with their technical and social division of work, composed of nurses, nursing auxiliaries and technicians, must be apt and competent to develop nursing activities. It is also necessary to have sufficient professionals for these tasks.

Nurses, as administrators, need to acquire management skills to grasp this scenario, learning about health service administration concepts, leadership, material and human resources. The latter includes personnel planning and provision to develop legally established activities that characterize the profession. Since nursing was institutionalized in healthcare structures, nurses have incorporated, as content of their work, a set of administrative actions that, because their execution is ruled by their own rationality criteria, are actually visible only to the extent that they comply with programs established by the institution ${ }^{(1)}$. This makes nurses reflect on the development of negotiation power, since they work directly with nursing human resources in health, focusing on the human being in a special situation at a given moment of life.

Moreover, the organizational policy significantly affects the nursing service. One example is cost reduction, which tends to affect the nursing team, leading to downsizing of personnel and/or not filling vacancies, which affects the quality of care delivery. For hospitals to comply with their mission, they count on a number of nursing staff members that traditionally correspond to the largest group of professionals hired.

In this reality, nursing human resources demand more professionals, more cases of dismissal, hours of training and improvement, among other costs $^{(2)}$, which permits the interference of professionals from other specialties in their dimensioning, potentially causing legal damage to nursing and institution. Thus, qualitative and quantitative aspects of nursing personnel have attracted the attention of direct nursing service managers, due to the implications of inadequate dimensioning for the outcomes of nursing care delivery to the clientele ${ }^{(3)}$.
Dimensioning constitutes "the adaptation of personnel in quantitative and qualitative terms ${ }^{\prime \prime(4)}$. It can be also defined by its final purpose, which is "planning the quantity of employees per category, required in order to fulfill, directly or indirectly, the patients' nursing care needs" ${ }^{\prime \prime}$.

Yet, we agree that "it is through this client/ nursing relation that we can have support to justify an ideal number of nursing personnel" ${ }^{\prime(6)}$.

Considering the work load at the units under study, dimensioning is "understood as a systematic process that bases planning and evaluation of the number and quality of nursing personnel needed to provide nursing care, to guarantee the previously established quality, to a group of patients/clients, according to the organization's philosophy and structure, as well as the singularity of each service" ${ }^{\prime(7)}$.

In view of the authors cited, dimensioning attempts to plan a sufficient number of personnel per category to develop nursing activities according to the client's need, considering the quality of care and then, providing units with these human resources.

It is one of the administration instruments nurses have at their disposal as knowledge focused on the management function, legally established as their competence, aimed at planning the number of nursing professional, from a qualitative and quantitative perspective, able to attend the client's care needs at public or private health service units.

Keeping in mind that all nurses acquire, in their basic education, clinical, collective health and administrative knowledge, it is up to them to develop it, through the acquisition of skills and competences to discuss this knowledge. Support is also given in the Professional Practice Law, Resolution COFEN-293/ 2004, where "it is up to the nurse to establish the quantity and quality of professionals needed to deliver nursing care" ${ }^{\prime(8)}$.

Based on these considerations, the objectives of this study are to conceptualize nursing staff dimensioning according to professionals who execute this task and know the purpose and use of nursing human resource estimates.

\section{METHODOLOGY}

To reach the proposed objectives and develop the theme under study, an exploratory descriptive research with a qualitative approach was carried out. 
The study was carried out in Ribeirão PretoSP. First, nine General Hospital managers and their respective nursing coordinators in Ribeirão Preto were asked for their authorization. Three of these hospitals formally refused to participate and one did not answer, even after several telephone contacts, while five agreed to participate, through the authorization mentioned above.

When asking to schedule the interview with the persons responsible for nursing staff dimensioning, the answer obtained was that the nursing coordinator was responsible. Hence, the study participants were the five nursing coordinators who accepted to participate in the study.

Data were collected in June and July 2003 through an interview, guided by a three-question script: What do you understand as nursing staff dimensioning? For what purpose do you use nursing staff dimensioning? How do you use nursing staff dimensioning in your practice? The data collection instrument was submitted to validation by a group of six experts. Information used in the research was recorded.

This research project was submitted to and approved by the Research Ethics Committee at EERP-USP. After orientation on the study objectives, the nursing coordinators agreed to participate in the study and authorized the use of the information.

To contemplate the research proposal, content analysis was used ${ }^{(9)}$. Thus, answers obtained through interviews were fully transcribed, respecting the terminology used by the study participants, according to familiarity with these answers and using repetitive content readings

The significant descriptions were determined and selected, with a view to maintain or abstracting the essence of the research participants' statements.

In the rigorous re-reading of categorizations, the aim was to identify propositions that permitted generalizations, also identifying potential divergences and convergences.

From the exhaustive reflection on the material, inferences and their variables emerged, forming the construction of the knowledge desired in this study. However, there was no intent on exhausting it but, on the contrary, the idea was to make it apt to discuss the obtained categories: concept, purpose and use of nursing staff dimensioning.

\section{RESULT AND DISCUSSION}

Regarding the dimensioning concept, the nursing coordinators evidenced a consensus on the idea of quantity and/or number the word implies.

...it is the adequate number of professionals according to the needs of the institution... it is managing to determine a number adequate to its needs ( $E-1)$.

...it is the quantity of professionals I have on my staff, right. For each sector, a quantity, if it is per number of patients, if it is by complexity of hospitalization cases (E-2).

...it is a methodology used, based on scientifically proved parameters to establish the necessary number of personnel for the exercise of nursing activities at that unit, complying with the characteristics of both the clientele and the specificity of each unit (E-3).

$\ldots$ is the adequate number of people working in that sector, that institution according to the need required by the activity (E-4).

...number of employees able to attend that client... (E-5).

It is inferred, from these manifestations, that dimensioning means an adequate personnel quantity for the realization of hospital nursing activities according to the number of patients, complexity of care and institution's sector. It entails the idea of flexibility conferred to the estimate by the term adaptation.

The coordinators refer to the characteristics of the work, which permits inferring about the dynamic and complex dimension involved in this calculation as, even in the institution, each sector has its peculiarities.

Dimensioning can be conceived in a qualitative focus, which transcends the merely mathematic aspect. The importance of adopting care systematization and the flexibility of this number is also highlighted. This thought reinforces the concern with personnel planning based on literature, which supports the need to discuss its provision.

Thus, it is inferred that the manifestations regarding the dimensioning concept were consensual, in terms of the expression of quantity, number, and that this concept is broadened in view of each coordinator's contextualization for this calculations. Thus, it is believed that it is based on this understanding that planning is put into operation, which will represent the number of personnel relevant for the execution of nursing activities, of each institution, representative to meet the expectations of clients and professionals inserted in this service. 
These considerations are in accordance with the concept found in literature ${ }^{(5,7)}$.

Considering the authors cited, it is inferred that dimensioning seeks to preview a sufficient number of personnel, per nursing category, to perform professional activities according to the client's need. It can be noted that the nursing coordinators interviewed confirm this understanding.

Attempts were made to discover, through the coordinators, for what purpose they perform dimensioning. It was showed that they compute, for the planning of nursing human resources needed to meet the care demand and consequent execution of the work process, according to its multiple professional dimensions. Thus, it is understood that the purpose of dimensioning "...is the planning of employee quantities per category, required to meet the nursing care needs, directly or indirectly delivered to the clientele $\mathrm{e}^{\prime(3,5)}$.

It is observed that the purpose can refer to the execution of the nursing work per se, according to the philosophy of the nursing service at each institution.

To meet the objectives, goals of nursing service according to the pre-established regimen at this service. Thus, an adequate dimensioning according to my staff is needed to meet these goals. I need to have an adequate dimensioning to deliver quality nursing care. Basically, the final goal of dimensioning is to meet the clients' needs ( $E-1)$.

Another aspect on the goal of dimensioning refers to the client's expectations regarding his(er) needs, manifested as follows:

I attempt to dimension in order to establish care parameters... assure safety to the patient, a surveillance system able to meet the minimum requirement the patient demands, not only physical, but also emotional. It is to share, it is an issue of professional identification with the patient... (E-3).

It is revealed that the goal of dimensioning consists in establishing parameters of nursing care or, yet, to assure a surveillance system able to meet the patient's slightest physical and mental demand. It is evident that meeting the client's needs is initiated with the provision of nursing human resources.

The goal of dimensioning was also expressed here as the provision of nursing human resources for the sectors.

Provide the care sectors with the necessary workforce, to deliver quality care (E-4).

It is also highlighted that the phase of nursing personnel planning for a sector precedes its hiring and distribution among related sectors.
The non use of dimensioning was also reported, perceiving a certain confusion between staff dimensioning and distribution (scale).

I don't use dimensioning a lot. I can see the dimensioning better when it is on the scale, this thing of day off, vacation, I can have a global view. I can't talk like five here in the clinic will work $(E-5)$.

...we develop activities with a very tight scale, so we cannot work much with dimensioning. Employee in the staff, for them it is always too little and you never manage to meet a scale, though I am sure that mine is not sufficient (E-2).

The reports appoint that the purpose of nursing staff planning attributed to dimensioning is implicit and was described differently, highlighting the most used expressions:...to meet the objectives and purpose of the nursing service .../ meet the smallest demand.../... provide the care sectors with the necessary work force.

In view of the exposed, it can be inferred that there is no consensus among the interviewees about the purpose of planning, with a lack of clarity and some confusion with staff distribution. Two coordinators emphasize provision as the purpose of dimensioning, which is in accordance with literature ${ }^{(5)}$.

The inquiry about whether the coordinator uses staff dimensioning in practice and the way (s)he uses it makes us think that it is related to a management instrument for the nurse to negotiate on a staff increase, with a view to a quantitative adaptation to the experienced reality, assuring a minimum acceptable care standard to maintain the quality of patient care and the nursing team members' satisfaction.

The use of dimensioning as a justification to increase nursing staff through hiring was emphasized.

I use it a lot because I work with quality, with production ratios. So I have a notion of what each area produces per employee... Actually, I use dimensioning a lot whenever I ask for a staff increase or when I analyze a staff group. I interconnect this with the productivity issue, with the kind of patient I attend. I do not stick to formulas a lot, I know there are those formulas. But actually. $I$ also end up relating it to each sector's reality ( $E-1)$.

...We always use an empirical kind of dimensioning, much more based on our experience of needs, never taking into account the issue of clientele characteristics attended in terms of nursing care hour demands. It was adopted because, over the years, we had a great need to prove that a certain number was needed and, nevertheless, even showing that based on experience, this number was always under-dimensioned in view of our desire in terms of this reference framework... we adopted as criterion, at least in the last 10 years, to calculate a number per shift (E-3). 
...I have a distribution of daily functions, per shift, in case there is a person lacking in the routine during the whole month, in one month I will have a loss in the final work production results, I use it (dimensioning) daily in all sectors, the evaluation is constant... for instance, I did a job that was approved now for the need for nurse and auxiliaries. I surveyed it during 6 months, presented the movement reports, hospitalizations, patients/day, with the specific characteristics, like at the ICU, I cannot consider patients/day, I have to see how many rooms were opened... have to evaluate countless variables, so all of them compose a study that leads to a demand for staff increase ( $E-4)$.

It is inferred that the use of dimensioning can support arguments to increase the staff, granting credibility in negotiations for hiring and equipping the nurse in this administrative function. In this sense, we agree that nursing service coordinators seek instruments that permit better management of the human resources under their responsibility, looking for knowledge, competencies and abilities that allow them to perform planning, allocation, distribution and satisfactory control of nursing personnel, assuming a relevant role in staff negotiations and human resource policy orientations at health institutions ${ }^{(10)}$.

It is inferred that dimensioning is also used to adjust the number of employees, to establish a work routine, according to this number, and to assure productivity.

Another aspect observed refers to the use of the report about hospitalization, movement, patient/ day as an argument for hiring, data which compose the personnel estimate.

For staff dimensioning at the material department, we use our reality and historical data (E-1).

To dimension nursing human resources, a preliminary study is recommended in order to diagnose the peculiarities of each service, characterizing the institution, service and clientele ${ }^{(6)}$. Putting this planning process into operation requires the application of a method that permits interrelating and measuring the variables that interfere in the work load $^{(11)}$

It seems the coordinators are not very familiar with the use of the calculation itself, there seems to be some resistance, even when they verbalize the guiding parameters of the planning methods.

I don't use dimensioning. I go like, sometimes a nurse who is responsible for that sector says, for instance, I have a sector with 28 surgical clinic pre and post surgery patients, the number of staff is good during the day but super tight at night, a hyper tight one, but then we see that the service works perfectly well in the morning and in the afternoon, with some little problems at night... So, both the nurse and I saw that there was a need to have at least three in each night shift (E-2).

On the one hand, the non use of dimensioning can be perceived and, on the other, its focus on reallocating personnel, that is, on internal rotation. The statement below shows the non use of personnel estimates and demonstrates concern with seeking to maintain the daily distribution scale.

I don't use dimensioning. I go for the employee's agility, I count on the employee's experience and commitment to the client...At the hospital, it is also a problem because there is no constant hospitalization curve ... I have to be prepared for times of high demand...But I don't know if it is Thursday, it is not every Thursday... Now, there are weeks employees stay there at the unit sitting, cutting cotton, cleaning drawers and papers... and there are days that I get here and, when I leave, there are ten clients hospitalized in the whole hospital and, when I arrive the next morning, it is a new surprise for me, always... How can I hire an employee? And I cannot have an over crowed staff, but it is not tight either (E-5).

Coordinators who report using dimensioning appoint aspects focused on staff estimation parameters and their relation with the dynamics of nursing work and the institution. On the other hand, those who do not use it emphasize concern with monthly, daily and vacation scale distribution.

In view of this reality, the quantitative and qualitative planning of human resources is a process that depends on the knowledge of the work load existent in the sectors, which in turn depends on the patient's needs, as well as on the intended care standard $^{(11)}$.

\section{CONCLUSION}

This study originated from the need to get to know the concept, purpose and way in which nurses use nursing human resource dimensioning in their professional practice.

Regarding the dimensioning concept, the research allows to define it as the planning of a sufficient number of staff members per nursing category to perform the professional activities according to the client's need, considering also the quality of care. This definition is in accordance with those found in literature.

Regarding the purpose of this estimate, besides planning these professionals, there is the assurance of 
putting nursing work into operation and meeting the client's expectation regarding his(er) needs; the provision of personnel sectors and the assurance of their distribution across the employee scale.

The findings show that dimensioning is used as a justification to raise the number of employees through hiring. It is also used to adjust the number of employees and to establish work routine accordingly.
Coordinators who emphasize its non use express concern with the distribution of monthly, daily and vacation scales.

Based on this study, it can be affirmed that: nurses have not used all instruments for nursing staff dimensioning; know about their needs, but have not managed to implement and develop these instrument to adapt the number of human resources.

\section{REFERENCES}

1. Laus AM. Dimensionamento de pessoal de enfermagem para unidades de internação médicas e cirúrgicas da Faculdade de Medicina de Ribeirão Preto-USP [tese]. Ribeirão Preto (São Paulo): Escola de Enfermagem de Ribeirão Preto/ USP; 2003.

2. Antunes AV, Costa MN. Dimensionamento de pessoal de enfermagem em um hospital universitário. Rev Latino-am Enfermagem 2003 novembro-dezembro; 11(6):832-9.

3. Gaidzinski RR, Kurcgant, P Dimensionamento do pessoal de enfermagem: vivência de enfermeiras. Rev Nursing. 1998 julho; 1(2):28-34.

4. Magalhães AMM, Duarte ERM, Moura GMSS. Estudo das variáveis que participam do dimensionamento de pessoal de enfermagem em hospitais de grande porte. Rev Gaúch Enfermagem 1995; 16(1/2):5-16.

5. Amorim CVT, Façanha AAA, Barros JMHA. Dimensionamento quantitativo e qualitativo dos recursos humanos da unidade Feminina do Hospital Universitário Regional do Paraná. Rev Divulgação. 1996; 15:38-42.

6. Santos SR. Cálculo de pessoal de enfermagem: estudo de dois métodos. Rev Esc Enfermagem USP. 1992;26(2):13754.

7. Gaidzinski RR, Fugulin FMT, Castilho, V Dimensionamento de pessoal de enfermagem em instituições de saúde. In: Kurcgant P, coordenadora. Gerenciamento em enfermagem. Rio de Janeiro (RJ): Guanabara Koogan; 2005. p.125-137.

8. Conselho Regional de Enfermagem de São Paulo. Resolução COFEn-293, de 21 de setembro de 2004, que Fixa e estabelece parâmetros para o Dimensionamento do Quadro de Profissionais de Enfermagem nas unidades assistenciais das instituições de saúde e assemelhados. Disponível em http://www.corensp.org.br Acesso em: 19 de jul. 2006.

9. Bardin L. Análise de conteúdo. Lisboa: Persona; 1977.

10. Fugulin FMT Dimensionamento de pessoal de enfermagem: avaliação do quadro de pessoal das unidades de internação de um hospital de ensino [tese]. São Paulo (SP): Escola de Enfermagem/USP; 2002.

11. Gaidzinski RR. O dimensionamento do pessoal de enfermagem em instituições hospitalares [tese]. São Paulo (SP): Escola de Enfermagem/USP; 1998. 